\title{
Evaluation of empirical antibiotic usage and cost analysis of patients with nosocomial pneumonia in ICU of Dr. Sardjito General Hospital, Yogyakarta
}

\author{
Minar Paskah Lianti Manik ${ }^{1}$, Rizka Humardewayanti Asdie ${ }^{2}$, Ika Puspitasari ${ }^{3 *}$ \\ ${ }^{1}$ Masters in Clinical Pharmacy, Faculty of Pharmacy, ${ }^{2}$ Department of Internal Medicine, \\ Faculty of Medicine, Public Health and Nursing, ${ }^{3}$ Department of Pharmacology and \\ Clinical Pharmacy, Faculty of Pharmacy, Universitas Gadjah Mada, Yogyakarta
}

https://doi.org/10.22146/ijpther.573

\begin{abstract}
Submitted: $14 / 08 / 2020$

Accepted : 16/12/2020

Keywords:

antibiotic use;

rationality;

cost analysis;

nosocomial pneumonia; ICU;

The rationality of antibiotic usage has an implication on the therapeutic quality and antimicrobial resistance control. Qualitative and quantitative evaluation of this rationality becomes one quality indicator of hospitals' antimicrobial resistance programs. This study aimed to investigate the relationship between the rationality of antibiotic usage with clinical outcomes and the total cost in nosocomial pneumonia patients treated in the intensive care unit (ICU) of Dr. Sardjito General Hospital, Yogyakarta. This was a descriptive-analytic observational study with a cross-sectional design. Data were collected retrospectively from the medical and financial record of patients who met the inclusion and exclusion criteria. The data were then analyzed descriptively using the Gyssens flowchart. Fisher statistical test was conducted to analyze the relationship between rationality data and therapeutic outcomes. Furthermore, the Mann Whitney statistical test was conducted to evaluate the relationship between rationality data and the cost, while the paired t-test was conducted to analyze the resistance pattern. The results showed that antibiotic usage in patients with nosocomial pneumonia at the ICU of Dr. Sardjito General Hospital was irrational and rational by $30.21 \%$ (29 regimens) and $69.79 \%$ (67 regimens), respectively. This rationality has a relation with clinical outcome $(\mathrm{p}=0.001)$, however it has no a relation with the antibiotics cost $(\mathrm{p}=0.900)$.
\end{abstract}

\begin{abstract}
ABSTRAK
Penggunaan antibiotik yang rasional mempunyai implikasi terhadap kualitas terapi dan resistensi antimikroba. Evaluasi secara kuantitatif dan kualitatif terhadap rasionalitas penggunaan anti mikroba ini menjadi salah satu indicator kualitas program penanggulangan resistensi antibiotik di rumahsakit. Penelitian ini bertujuan untuk mengkaji hubungan antara rasionalitas penggunaan anti biotic dengan luaran klinik dan biaya pengobatan pasien pneumonia nosokomial yang dirawat di unit perawatan intensif (ICU) RSUP Dr. Sardjito, Yogyakarta. Penelitian ini merupakan penelitian observasi onaldiskriptif-analitik dengan rancangan potong lintang. Data diambil secara retrospektif dari rekammedik dan pembiayaan pengobatan pasien yang memenuhi criteria inklusi dan eksklusi. Data selanjutnya dianalisis secara deskriptif menggunakan diagram alir Gyssens. Analisis Fisher digunakan untuk mengkaji hubungan antara rasionalitas data dan luaran klinik. Selanjutnya, uji Mann Whitney dilakukan untuk mengkaji hubungan rasionalitas data dan biaya, sedangkan uji t pasangan dilakukan untuk menganalis apolaresistensi. Hasil penelitian menunjukkan penggunaan antibiotic pada pasien pneumonia nosokomial di ICU RSUP Dr. Sardjito yang tidakrasional dan rasional berturut-turut sebesar 30,21\% (29 peresepan) dan $69,79 \%$ (67 peresepan). Tingkat rasionalitas ini berhubungan dengan luaran klinik $(p=0,001)$, akan tetapi tidak berhubungan dengan biaya pengobatan $(\mathrm{p}=0,900)$.
\end{abstract}




\section{INTRODUCTION}

Pneumonia is a type of lower respiratory tract infection that remains major cause of mortality and morbidity in hospitals. The types of pneumonia include hospital-acquired pneumonia (HAP), healthcare-associated pneumonia (HCAP) and ventilator-acquired pneumonia (VAP). Hospital-acquired pneumonia is generally reported in hospitalized patients within $48 \mathrm{~h}$ or more after being admitted. ${ }^{1}$ Patients of HAP with severe conditions are treated in the intensive care unit (ICU), and about $10 \%$ of them acquire pneumonia, which increases their incidence in patients with breathing aids by $20-30 \%{ }^{2}$ However, mortality and morbidity rates are generally higher in large hospitals compared to the smaller size.

In Indonesia, pneumonia is a cause of hospital mortality with a prevalence percentage of $4.5 \%$ in the same year. ${ }^{3}$ Unfortunately, Yogyakarta City has a slightly higher prevalence percentage than the national value of $4.6 \% .^{4}$ The evaluation of antibiotic usage refers to the prescription of rational antibiotics. This is not only expected to affect the therapy quality, but also the antimicrobial resistance control. One of the indicators of this programs in hospitals is the evaluation of antibiotic use both qualitatively and quantitatively.

The studies on the rationality of antibiotic use have been conducted based on Gyssens' flow and cost analysis in patients with nosocomial pneumonia. However, it offers several differences in the analysis method, sample, location, and research period. It aimed to determine the appropriateness profile of antibiotic usage, as well as the relationship between its rationality to clinical outcomes and total costs.

\section{MATERIALS AND METHODES}

\section{Design \\ This studyused a descriptive-analytic observation with a cross-sectional}

design analysis. Data were collected retrospectively from medical and billingrecords. Furthermore, the cost of illness based on the incident approaches was implemented in the cost analysis. The data collected from medical records aims to determine the use of antibiotics and therapeutic outcomes. Meanwhile, those from the financial records of Dr. Sardjito General Hospital's accounting department was used to obtain cost data based on the perspective of health care providers i.e. direct costs in the form of therapy (antibiotics, drugs, and medical devices), medical (visite, consultation, and nursing), accommodation, supporting examination (laboratory and diagnostic), and the total cost of care.

\section{Procedure}

The subjects of this study were medical records and billing data recap of nosocomial pneumonia patients who were treated in the ICU ward of RSUP Dr. Sardjito General Hospital in the period of January $1^{\text {st }}, 2015$ - December $31^{\text {st }} 2016$ and met the inclusion as well as exclusion criteria. Inclusion criteria in this study include ICU patients with a diagnosis of nosocomial pneumonia (HAP, HCAP, and VAP), adult ICU patients aged $\geq 15$ years, and patients with complete medical record and financial recap, i.e. age, laboratory results, treatment history, as well as clinical outcome parameters. Meanwhile, the exclusion criteria were pregnant women, forced discharged patients, and ICU treatment days $<48 \mathrm{~h}$.

\section{Statistical analysis}

The data were presented as frequency and then analyzed descriptively using the Gyssens flowchart. Fisher statistical test was conducted to analyze the relationship between rationality data and therapeutic outcomes. Furthermore, the Mann Whitney statistical test was conducted to evaluate the relationship between rationality data and the cost, while the paired t-test was conducted to analyze the resistance pattern. 


\section{RESULTS}

A total of 110 patients who diagnosed with nosocomial pneumonia during treated in the ICU were selected. Only
61 patients consisting 24 HAP, 24 HCAP, and 13 VAP who met the inclusion and exclusion criteria were involved in this study. The characteristics ofsubjects are presented in TABLE 1.

TABLE 1. Characteristics of nosocomial pneumonia patients $(n=61)$ in ICU of Dr. Sardjito General Hospital from 2015 to 2016.

\begin{tabular}{|c|c|c|c|c|}
\hline Characteristics of patients & $\begin{array}{l}\text { HAP } \\
{[n(\%)]}\end{array}$ & $\begin{array}{l}\text { HCAP } \\
\text { [n (\%)] }\end{array}$ & $\begin{array}{c}\text { VAP } \\
\text { [n (\%)] }\end{array}$ & $\begin{array}{c}\text { Total } \\
\text { [n (\%)] }\end{array}$ \\
\hline \multicolumn{5}{|l|}{ Age } \\
\hline • $18-59$ & $16(26.2)$ & $13(21.3)$ & $10(16.4)$ & 39 (63.9) \\
\hline$\bullet \geq 60$ & $10(16.4)$ & $9(14.8)$ & $3(4.9)$ & $22(36.1)$ \\
\hline \multicolumn{5}{|l|}{ Gender } \\
\hline - Male & $13(21.3)$ & $14(23.0)$ & $8(13.1)$ & $35(57.4)$ \\
\hline - Female & $13(21.3)$ & $8(13.1)$ & $5(8.2)$ & $26(42.6)$ \\
\hline \multicolumn{5}{|l|}{ Class of treatment } \\
\hline • VIP & $2(3.3)$ & $1(1.6)$ & $0(0)$ & $3(4.9)$ \\
\hline - Class I & $9(14.8)$ & $4(6.6)$ & $2(3.3)$ & $15(24.6)$ \\
\hline - Class II & $4(6.6)$ & $6(9.8)$ & $2(3.3)$ & $12(19.7)$ \\
\hline - Class III & $11(18.0)$ & $11(18.0)$ & $9(14.8)$ & $31(50.8)$ \\
\hline \multicolumn{5}{|l|}{ Health insurance } \\
\hline - Public & $1(1.6)$ & $3(4.9)$ & $3(4.9)$ & $7(11.5)$ \\
\hline • NHI & $10(16.4)$ & $10(16.4)$ & $7(11.5)$ & $27(44.3)$ \\
\hline - Non-NHI & $15(24.6)$ & $9(14.8)$ & $3(4.9)$ & $27(44.3)$ \\
\hline \multicolumn{5}{|l|}{ LOS } \\
\hline$\bullet<14$ days & $20(32.8)$ & $18(29.5)$ & $8(13.1)$ & $47(77.1)$ \\
\hline$\cdot \geq 14$ days & $6(9.8)$ & $4(6.6)$ & $5(8.2)$ & $14(22.9)$ \\
\hline
\end{tabular}

Note. NHI: National Health Insurance (Jaminan Kesehatan Nasional Penerima Bantuan Iuran); Non-NHI: National Health Insurance (Jaminan Kesehatan Nasional Tidak Penerima BantuanIuran); LOS (length ofstay).

Empiric single and combination antibiotics therapeutic regimens in the nosocomial pneumonia patients were observed in this study. Penicillin (ampicillin, ampicillin / sulbactam), cephalosporin (ceftriaxone, cefotaxime, cefepime, cefoperazone / sulbactam), quinolones (ciprofloxacin, levofloxacin), macrolides (azithromycin), aminoglycosides (amikacin, gentamicin), monobactam (aztreonam), a carbapenem (meropenem, imipenem), antifungal (fluconazole, micafungin), glycylcyclines (tigecycline), and others (metronidazole, phosphomis) were used in the 96 therapeutic regimens.The regimens were changed if the clinical outcome was unimproved or worsened. Therefore, a patient might receive several regimens. 
Analysis of irrational use of antibiotics

The Gyssens flowchart method was used to evaluate the irrational use of the antibiotics. The antibiotic therapywas considered appropriate (category 0 ) if it passed the analysis stages of categories IV to I. This analysis was conducted by comparing standards antibiotic treatment for nosocomial pneumonia patients from several guidelines i.e, ATS 2005, Dr. Sardjito General Hospital
Antibiogram 2014 and IDSA/ATS 2016.,6 The irrational use of antibiotics in this study was obtained in 6 categories, i.e., $\mathrm{V}$, IVA, IVB, IVC, IIA, and IIB (TABLE 2). The greatest contributor to the irrational use of antibiotics was the IIA category with dose accuracy of 25\% from 67 irrational regimens (69.8\%). Furthermore, category $\mathrm{V}$ showed the presence or absence of indications in the treatment of antibiotics up to $17.7 \%$ or 17 antibiotic regimens.

TABLE 2. Irrational use of antibiotic based on Gyssens flowchart

\begin{tabular}{|c|c|c|}
\hline $\begin{array}{l}\text { Irrational use } \\
\text { of antibiotic }\end{array}$ & Category & $\begin{array}{c}\text { Number of regimens } \\
{[\mathrm{n}(\%)]}\end{array}$ \\
\hline \multirow{2}{*}{ Rational } & 0 & $29(30.2)$ \\
\hline & Sub total & $29(30.2)$ \\
\hline \multirow{8}{*}{ Irrational } & $\mathrm{V}$ & 17 (17.7) \\
\hline & IVA & $11(11.5)$ \\
\hline & IVB & $1(1)$ \\
\hline & IVC & $1(1)$ \\
\hline & IIA & $24(25)$ \\
\hline & IIB & $13(13.5)$ \\
\hline & Sub total & $67(69.8)$ \\
\hline & Total & $96(100)$ \\
\hline
\end{tabular}

\section{Irrational use of antibiotics and clinical outcomes}

De-escalation is one strategy that allows for the initiation of appropriate broad-spectrum antibiotics therapy for nosocomial pneumonia patients based on patient risk factors and clinical presentation. Patients are then re-evaluated at 24 to $48 \mathrm{~h}$ of therapy based on clinical outcomes and results from microbiological evaluations. ${ }^{7}$ The clinical outcomes in nosocomial pneumonia patients can be assessed from several parameters, which include leukocyte count, body temperature, and oxygenation. ${ }^{8}$ Based on several clinical criteria included body temperature $\leq$ $38^{\circ} \mathrm{C}$, respiratory rate $/ \mathrm{RR} \leq 22 \mathrm{x} / \mathrm{min}$, systolic blood pressure $\geq 100 \mathrm{mmHg}$, total leukocyte count $\leq 10,000 / \mathrm{mm}^{3}$, and the chest radiograph results, the results of this study was considered good. TABLE 3 shows the outcomes of 96 antibiotic regimens based on the Gyssens flow method category. 
TABLE 3. Clinical outcome for each antibiotic regimen of patients with nosocomial pneumonia

\begin{tabular}{lccc}
\hline \multirow{2}{*}{ Category } & \multicolumn{2}{c}{ Clinical outcome } \\
& \multicolumn{2}{c}{ [n (\%)] } & \multirow{2}{*}{ Total } \\
\cline { 2 - 3 } & Good & Bad & \\
\hline Rational & $10(34.5)$ & $19(65.5)$ & 29 \\
Irrational & & & \\
- V & $0(0)$ & $17(100)$ & 17 \\
- IVA & $0(0)$ & $11(100)$ & 11 \\
- IVB & $0(0)$ & $1(100)$ & 1 \\
- IVC & $0(0)$ & $1(100)$ & 1 \\
- IIA & $4(16.7)$ & $20(83.3)$ & 24 \\
- IIB & $0(0)$ & $13(100)$ & 13 \\
Total & $14(14.6)$ & $82(85.4)$ & 96 \\
\hline
\end{tabular}

Base on the clinical outcomes, it was reported in this study that the number of bad outcomes is greater than the good ones by 82 . This is related to the characteristics of nosocomial pneumonia patients in the ICU, such as comorbidity. All nosocomial pneumonia patients in the ICU of Dr. Sardjito General Hospital have more than one comorbid disease, hence have a high rate of comorbidity. To assess its non-infectious level, a Charlson comorbidity index (CCI) score is assessed and was statistically analyzed concerning the clinical outcome of nosocomial pneumonia patients in the ICU.

Fisher test was conducted to determine the relationship between non- infectious comorbidities (CCI scores) and clinical outcomes since they did not meet the Chi-square test requirements. As shown in TABLE 4 that the comorbidities are significantly associated with the clinical outcome of nosocomial pneumonia patients in the ICU $(p<0.05)$. Furthermore, only 3 patients with CCI scores $\geq 3$ had good outcomes, meaning that those with high comorbid rates were predominantly having bad outcomes. A Chi-square test was conducted to determine the relationship between rationality and clinical outcome. In statistical calculations, using the Fisher test due to statistical cells, which have an expected value of $<5$ with a percentage of greater than $20 \%$.

TABLE 4. Fisher analysis results of the nosocomial pneumonia patients CCI score toward the clinical outcome of ICU of Dr. Sardjito General Hospital in $2015-2016$

\begin{tabular}{|c|c|c|c|c|c|}
\hline & & \multicolumn{2}{|c|}{ Outcome } & \multirow{2}{*}{$\mathrm{p}$} & \multirow{2}{*}{ OR } \\
\hline & & Good & Bad & & \\
\hline \multirow{2}{*}{$\begin{array}{l}\text { Total CCI } \\
\text { Score }\end{array}$} & $\mathrm{CCI} \leq 2$ & $11(37.9 \%)$ & $18(62.1 \%)$ & \multirow{2}{*}{$0.013^{*}$} & \multirow{2}{*}{5.90} \\
\hline & $\mathrm{CCI} \geq 3$ & $3(9.4 \%)$ & $29(90.6 \%)$ & & \\
\hline
\end{tabular}

Notes: Fisher test: ${ }^{*}$ statistically significant $(p<0.05)$ 
A total of 29 rational antibiotic regimens had 10 bad clinical outcomes. Meanwhile, irrational antibiotics regimens had only 4 good clinical outcomes from 67 regimens used (TABLE 5). A significantly relationship between the rational use of antibiotics and the clinical outcomes was observed $(p<0.05$;
$\mathrm{OR}=8.28$ ). The rational use of antibiotics on patients with nosocomial pneumonia has the possibility of 8.28 times resulting in improvement of clinical outcomes. In addition, the irrational antibiotics regimens categories were related to the clinical outcomes (TABLE 3).

TABLE 5. Fisher analysis results on the rationality of antibiotic use of nosocomial pneumonia patients toward clinical outcomes of ICU Dr. Sardjito General Hospital in 2015-2016

\begin{tabular}{|c|c|c|c|c|}
\hline & \multicolumn{2}{|c|}{ Outcome } & \multirow{2}{*}{$\mathrm{p}$} & \multirow{2}{*}{ OR } \\
\hline & Good & $\mathrm{Bad}$ & & \\
\hline Rational & $10(34.5 \%)$ & 19 (65.5\%) & \multirow{2}{*}{$0.001^{*}$} & \multirow{2}{*}{8.28} \\
\hline Irrational & $4(5.9 \%)$ & 63 (94.1\%) & & \\
\hline
\end{tabular}

\section{Cost analysis}

This analysis was conducted from the perspective of the health service providers, aiming to identify the cost components and measure the amount of each component in nosocomial pneumonia patients in the ICU room of Dr. Sardjito General Hospital. The cost components used were direct medical costs listed in TABLE 6, which include inpatient / accommodation, therapy, medical (doctor's visit and consultation fees, nursing costs), and supporting costs (laboratory and diagnostic examination costs). The therapy cost involves the total of medical devices, antibiotics, and non-antibiotic drugs. It was the largest percentage component of direct medical costs since it constitutes the total of medical equipment, non-antibiotic, and antibiotics drugs.

TABLE 6. Cost component of nosocomial pneumonia patients in ICU of Dr. Sardjito General Hospital in 2015-2016

\begin{tabular}{lccc}
\hline Cost type & Min-Max (IDR) & Average (IDR) & $\%$ \\
\hline Antibiotic costs & $100,584-23,205,355$ & $2,166,674$ & 13.9 \\
Accommodation fee & $0-12,900,000$ & $2,235,800$ & 14.3 \\
Supporting costs & $486,000-15,118,500$ & $4,453,984$ & 28.5 \\
Medical costs & $566,000-30,109,900$ & $6,790,253$ & 43.4 \\
Non-antibiotic drug costs & $1,068,572-31,658,361$ & $7,523,088$ & 48.1 \\
Therapy Cost & $2,188,634-63,428,124$ & $12,518,887$ & 64.9 \\
\hline Total cost & $3,002,500-55,198,496$ & $15,646,824$ & 100 \\
\hline
\end{tabular}




\section{Average and percentage of total maintenance cost components based on payer}

TABLE 7 provides the information of average and percentage of total maintenance component costs for general patients with JKN PBI, and JKN non-PBI. The therapy cost involves a total of non-antibiotic and antibiotics drugs, as well as medical equipment. Meanwhile, medical costs consisted of visitation and consultation costs, nursing, and action costs. Furthermore, supporting costs includes laboratory and radiological costs. The average cost of therapy, medical, and support costs, as well as the total cost of a patient with JKN PBI payment guarantee, is higher than other types with an average total cost of IDR 24,750,677.

The therapy cost constitutes the largest percentage component of total maintenance cost in all payment guarantees. This shows that the total cost of treatment was incurred not only based on guaranteed payment but also for the treatment and care. The need for treatment and care for patients with nosocomial pneumonia in the ICU is high due to clinical conditions including comorbidity and possible complications, which leads to more accurate handling and considerable costs.

TABLE 7. Average and percentage of total maintenance cost components based on a payer

\begin{tabular}{llllll}
\hline \multicolumn{1}{c}{ Payer institution } \\
\multicolumn{1}{c}{$\begin{array}{c}\text { Public (n=7) } \\
\text { Average } \pm \text { SD }\end{array}$} & $\%$ & $\begin{array}{c}\text { NHI (n=27) } \\
\text { Average } \pm \text { SD }\end{array}$ & $\%$ & $\begin{array}{c}\text { Non-NHI (n=28) } \\
\text { Average } \pm \text { SD }\end{array}$ & $\%$ \\
\hline $10,016,393 \pm 8,568,925$ & 49.4 & $13,895,568 \pm 10,226,898$ & 56.1 & $11,791,001 \pm 9,118,759$ & 52.8 \\
$1,585,714 \pm 1,500,000$ & 7.8 & $2,096,222 \pm 1,920,000$ & 8.5 & $2.621 .111 \pm 1,800,000$ & 11.7 \\
$6,589,714 \pm 6,285,000$ & 32.5 & $7,179,785 \pm 5,561,000$ & 29.0 & $6,406,278 \pm 4,527,500$ & 28.7 \\
$4,042,200 \pm 3,939,000$ & 19.9 & $4,928,463 \pm 3,630,375$ & 19.9 & $4,055,760 \pm 3,885,600$ & 18.2 \\
$20,278,558 \pm 21,421,061$ & 100 & $24,750,677 \pm 20,035,061$ & 100 & $22,338,757 \pm 14,924,835$ & 100 \\
\hline
\end{tabular}

Notes: 1 . Therapy cost, 2. Accommodation fee, 3. Medical cost (visite, consultation, nursing, and action), 4. Supporting cost (laboratory and radiology), 5. Total cost. NHI: National Health Insurance (Jaminan Kesehatan Nasional Penerima Bantuan Iuran); Non-NHI: National Health Insurance (Jaminan Kesehatan Nasional Tidak Penerima Bantuan Iuran);

\section{Length of stay (LoS)}

The conventional treatment duration indicated in the IDS/ATS for patients with nosocomial pneumonia was 7 to 21 days. However, it was varied between 2 - 52 days due to comorbidity and clinical condition of the patient. TABLE 8 shows the length of stay in an ICU (LoS ICU) compared to the average cost component of patients with nosocomial pneumonia. A significantly different between the accommodation costs for LoS $\leq 14$ days and LoS $>14$ days was observed $(p=0.016)$. In contrast, no significantly different between LoS and clinical outcomes of patients with nosocomial pneumonia treated in ICU was observed ( $p>0.73)$ as shown in TABLE 9. This is due to clinical conditions and high levels of severity and comorbidity. Patients with short or long stays generally tend to have unimproved clinical outcomes. 
TABLE 8. LOS toward an average of component costs for total maintenance

\begin{tabular}{llll}
\hline \multicolumn{1}{c}{ LOS in ICU (days) } & \multicolumn{1}{c}{$\leq 14$ days } & \multicolumn{1}{c}{$>14$ days } & \multicolumn{1}{c}{$\mathrm{p}$} \\
\hline Therapy cost (IDR) & $11.621 .647 \pm 7.047 .720$ & $15.270 .425 \pm 16.517 .659$ & 0.789 \\
Accommodation fee (IDR) & $1.644 .087 \pm 1.050 .172$ & $4.189 .333 \pm 3.701 .427$ & $0.016^{*}$ \\
Medical cost (IDR) & $6.278 .857 \pm 4.056 .078$ & $8.274 .953 \pm 7.824 .037$ & 0.75 \\
Supporting cost (IDR) & $4.515 .289 \pm 2.707 .132$ & $4.211 .076 \pm 3.293 .701$ & 0.492 \\
Total cost (IDR) & $14.158 .882 \pm 8.271 .808$ & $20.209 .844 \pm 13.768 .460$ & 0.112 \\
\hline
\end{tabular}

Notes: ${ }^{*} \mathrm{p}<0.05$ statistically significant (Mann Whitney test)

TABLE 9. Fisher analysis results of length of stay (LOS) toward clinical outcomes

\begin{tabular}{|c|c|c|c|}
\hline \multirow[t]{2}{*}{ Length of stay (LoS) } & \multicolumn{2}{|c|}{ Outcome } & \multirow{2}{*}{$\mathrm{p}$} \\
\hline & Good & Bad & \\
\hline$\leq 14$ days & 10 & 36 & \multirow{2}{*}{$0.73^{*}$} \\
\hline$>14$ days & 4 & 11 & \\
\hline
\end{tabular}

Notes: ${ }^{*} \mathrm{p}>0.05$ was not statistically significant

\section{Relationship between theirrational use of antibioticsand direct medical costs}

No significantly different between irrational use of antibiotics and costs of therapy, drug, antibiotic, medical, support, and total costs was observed ( $p>0.05)$ as shown in TABLE 10. However, there was different in accommodation fee between rational and irrational use of antibiotics. The accommodation fee in the rational use of antibiotics (IDR $3,195,250 \pm 2,430,000$ ) was significantly higher than that in the irrational use of antibiotics (IDR 1,818,610 $\pm 1,440,000$ ) $(\mathrm{p}=0.02)$.

TABLE 10. Cost component of nosocomial pneumonia patients in ICU of Dr. Sardjito General Hospital based on the irrational use of antibiotic

\begin{tabular}{llll}
\hline \multirow{2}{*}{ Cost types (IDR) } & \multicolumn{1}{c}{ Rational $(\mathrm{n}=10)$} & \multicolumn{1}{c}{ Irrational $(\mathrm{n}=41)$} & $\mathrm{p}$ \\
\cline { 2 - 3 } & \multicolumn{1}{c}{ Mean \pm SD } & \multicolumn{1}{c}{ Mean \pm SD } & \\
\hline Therapy Cost & $11,123,803 \pm 9,553,755$ & $13,199,416 \pm 10,182,229$ & 0.95 \\
Drug costs & $6,857,633 \pm 5,767,524$ & $7,847,700 \pm 5,741,995$ & 0.29 \\
Antibiotic costs & $2,090,025 \pm 1,368,255$ & $2,204,063 \pm 936,400$ & 0.90 \\
Accommodation fee & $3,195,250 \pm 2,430,000$ & $1,818,610 \pm 1,440,000$ & 0.02 \\
Medical costs & $7,792,690 \pm 6,693,001$ & $6,270,681 \pm 5,454,000$ & 0.25 \\
Supporting costs & $3,940,976 \pm 3,335,438$ & $4,684,144 \pm 3,991,000$ & 0.18 \\
Total cost & $17,018,942 \pm 15,852,855$ & $14,977,498 \pm 11,090,398$ & 0.39 \\
\hline
\end{tabular}

\section{DISSCUSSION}

The empiric antibiotics therapeutic consisted of 96 regimens including single and combination antibiotics. Patients in the ICU with nosocomial pneumonia had their treatment regimen changed when the clinical outcome was unimproved or worsened. Consequently, one patient mightreceive several regimens. ATS recommended monotherapy in early onset pneumonia, does not have risk of MDR. ${ }^{5}$ Fluoroquinolone, carbapenem and piperazine tazobactam shown 
effectively as monotherapy for pneumonia which is caused by non-MDR microorganism..$^{9}$ In the rational category, a combination of metronidazole with other antibiotics aims to treat anaerobic bacteria in patients with infections aside from pneumonia, i.e, diabetic ulcers (px12, px22, px26, px32, px37), and those with anaerobic and protozoal bacterial infections risk such as px05 SLE patients. Furthermore, The AMMI Canada guidelines on nosocomial pneumonia have shown that metronidazole has excellent activity against anaerobic bacteria, antibiotic breakpoints from the National Committee for Clinical Laboratory Standards approved and tentative breakpoints. ${ }^{10}$ It was also used in the therapy of px 27 and px36 peritonitis patients, and as well as becomes one of the treatment options in the management of peritonitis infection. A combination of antibiotic therapy with micafungin in px05 and px25 patients was used to treat fungal infections. Px05 patients have a primary SLE diagnosis with a risk of fungal infection due to an autoimmune condition. Meanwhile, px25 patients have a secondary diagnosis of candidiasis. Both patients were given micafungin to treat fungal infections. ${ }^{11}$

Thepotential CCI score on the therapy outcome obtained was 5.90, implying that the CCI score $\leq 2$ had a 5.9 times greater chance of improvement than the CCI score $\geq 3$. This was in accordance with the study conducted in the intensive care Unit of the ConsorciHospital, in Barcelona. That previous study elaborates that comorbidity was related to the prognosis or clinical outcome of patients with nosocomial pneumonia. ${ }^{12}$

All components of direct medical costs such as the average cost of therapy, accommodation fee, medical costs, supporting costs, and total costs for the treatment duration $>14$ days was greater than that for $\leq 14$ days. This was in accordance with the study conducted by Rosenthal et $a l .{ }^{12}$ that nosocomial pneumonia patients have a high rate of comorbidities, hence requiring longer treatment time and higher total costs.
These was no significant difference between rational and irrational use of antibiotic cost in this study $(p>0.05)$. This result is in accordance with the study conducted by Sutrisno et al. ${ }^{13}$ that reported no relationship between rational and irrational use of antibiotic costof the nosocomial pneumonia patients. A significant difference was obtained only in the relationship between irrational use of antibiotics and the consumables cost. Meanwhile, this study showed a significantly different between the irrational use of antibiotics and the accommodation cost of nosocomial pneumonia patients in the ICU $(p<0.05)$. However, this might be due to the length of stay and accommodation rates set by the hospital.

\section{CONCLUSION}

The irrational use of antibiotics is reported in $69.8 \%$ of patients with nosocomial pneumonia in the ICU of Dr. SardjitoGeneral Hospital, Yogyakarta which include $17.7 \%$ in category V, $11.5 \%$ in IVA, $1 \%$ in IVB, $1 \%$ in IVC, $25 \%$ in IIA, and $13.5 \%$ in IIB category. Furthermore, the irrational use of antibiotic has a relationship with the clinical outcomes. However, the cost of antibiotics in the rational useis not significantly different compared with the irrational use.

\section{ACKNOWLEDGEMENT}

We would like to thank the Director of Dr. SardjitoGeneral Hospital, Yogyakartafor allowing thisstudy.

\section{REFERENCES}

1. Mandell LA, Wunderink RG, Anzueto A, Bartlett JG, Campbell GD, Dean NC, et al. Infectious Diseases Society of America/American Thoracic Society consensus guidelines on the management of community-acquired pneumonia in adults. Clin Infect Dis 2007; 44(Supplement2):S27-72. https://doi.org/10.1086/511159

2. Leone M, Bouadma L, Bouhemad 
B, Brissaud O, Dauger S, Gibot S, et al. Hospital-acquired pneumonia in ICU. AnaesthCrit Care Pain Med 2018; 37(1):83-98.

h t t p s://d oi .org/10.1016/j . accpm.2017.11.006

3. Sulistyawati S, Sofiana L, Amala SK, Rokhmayanti R, Astuti FD, Nurfita D. Pneumonia a neglected disease: A mixed-method study on the casefinding program in Indonesia. AIMS Public Health 2020; 7(1):81-91.

h t t p s : / / d o i . or g / 10.3934 / publichealth.2020008

4. Badan Penelitian dan Pengembangan Kesehatan. Laporan Nasional RISKESDAS 2018. Jakarta: Kementrian Kesehatan Republik Indonesia, 2018. Available from: https://kesmas.kemkes.go.id/assets/ upload/dir_519d41d8cd98f00/files/ Hasil-riskesdas-2018_1274.pdf

5. American Thoracic Society/ Infectious Diseases Society of AmericaIDSA A. Guidelines for the management of adults with hospitalacquired, ventilator-associated, andhealthcare-as s ociated Pneumonia. Am J Respir Crit Care Med 2005; 171(4):388-416. https://doi.org/10.1164/rccm.200405644ST

6. Kalil AC, Metersky ML, Klompas M, Muscedere J, Sweeney DA, Palmer LB, et al. Management of adults with hospital-acquired and ventilatorassociated pneumonia: 2016 Clinical practice guidelines by the Infectious Diseases Society of America and the American Thoracic Society. Clin Infect Dis 2016; 63(5):e61-111. https:/doi.org/10.1093/cid/ciw353

7. Rostein C, Evans G, Born A, Grossman $\mathrm{R}$, Light RB, Magder S, et al. Clinical practice guidelines for hospitalacquired pneumonia and ventilatorassociated pneumonia in adults. Can J Infect Dis Med Microbiol 2008; 19(1):19-53. https://doi.org/10.1155/2008/593289

8. Dennesen PJ, van der Ven AJ, Kessels AG, Ramsay G, Bonten MJ. Resolution of infectious parameters after antimicrobial therapy in patients with ventilator-associated pneumonia. Am J Respir Crit Care Med 2001; 163(6):1371-5.

h t t p s://d oi .org/10.1164/ ajrccm.163.6.2007020

9. Singh N, Rogers P, Atwood CW, Wagener MM, Yu VL. Short-course empiric antibiotic therapy for patients with pulmonary infiltrates in the intensive care unit. A proposed solution for indiscriminate antibiotic prescription. Am J Respir Crit Care Med 2000; 162(2 Pt 1):505-11.

h t t p s://d oi.org/10.1164/ ajrccm.162.2.9909095

10. Barie PS, Rotstein OD, Dellinger EP, Grasela TH, Walawander CA. The cost-effectiveness of cefepime plus metronidazole versus imipenem/ cilastatin in the treatment of complicated intra-abdominal infection. Surg Infect 2004; 5(3):269-80. https//doi.org/10.1089/sur.2004.5.269

11. Pappas PG. Micafungin for candidiasis. Mycoses 2012; 55(s1):8-12. https://doi.org/10.1111/j.14390507.2011.02112.x

12. Rosenthal V, Guzman S, Migone $O$, Crnich $C$. The attributable cost, length of hospital stay, and mortality of central line-associated bloodstream infection in intensive care departments in Argentina: a prospective, matched analysis. Am J Infect Control 2003; 31(8):475-80.

h t tp s://doi .org/10.1016/j . ajic.2003.03.002.

13. Sutrisno E. Impact of irrational antibiotic therapy to hospital cost of care of pneumonia in patients in Dr. Sardjito Hospital. Acta Interna J Intern Med 2013; 3(2):67-71. https://doi.org/10.22146/acta $\% 20$ interna.5002 